\title{
Ethnic reasoning and early Christian identity: A Pauline theological perspective
}

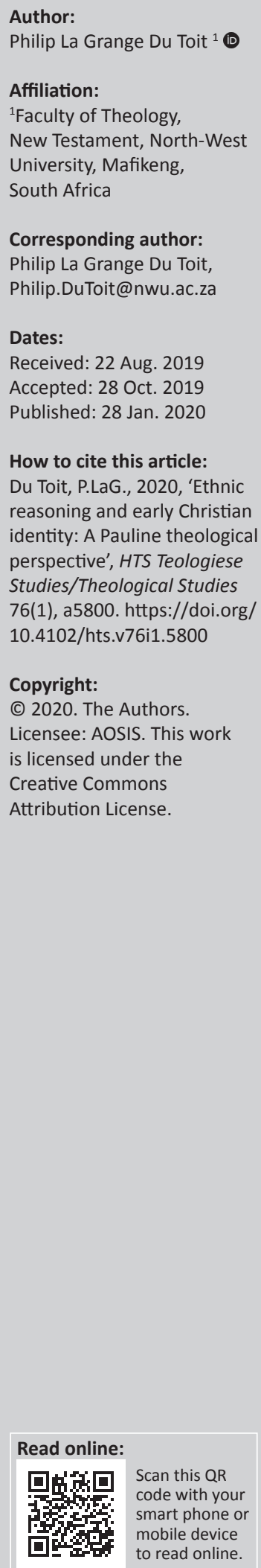

\begin{abstract}
Within the ethnic-reasoning position, which has gained momentum in recent years, it is argued that in the in-Christ identity there exists no dichotomy between natural, physical relationships and constructed, made-up relationships. Ethnicity is viewed as fluid and changeable and as including the category of religion, which is understood as involving a nation's culture and their cultic and ritualistic practices. Yet, it is a question whether these notions are compatible with the way in which the in-Christ identity is portrayed, especially by Paul. In terms of the theological way in which ethnicity and even religious practices are portrayed, they rather belong to the domain of humanness or human conduct, and thus to the anthropological domain. In contrast, believers' relation to Abraham and their new mode of identity in the S/spirit is portrayed as being in contrast with the anthropological domain or the domain of 'flesh', which includes things such as ethnicity, human conduct and even religious practices. This tension between divine identity and human or natural identity in the New Testament is accounted for and applied to the ethnic-reasoning position, which also influences the way in which the in-Christ identity finds cultural expression in the lives of present-day readers.
\end{abstract}

Keywords: ethnic reasoning; Pauline theology; ethnicity; kinship; religion; Spirit; flesh.

\section{Introduction}

In recent years, the concept of 'ethnic reasoning' has gained momentum in New Testament scholarship (e.g. Buell 2005; Concannon 2014; Harrill 2014; Horrell 2016; Johnson Hodge 2007; Sechrest 2009). The intent behind this concept is probably best described by Johnson Hodge (2007:4), who argues that ethnic reasoning is 'a new way to read kinship and ethnic language in Paul that dismantles the contrast between a universal, "non-ethnic" Christianity and an ethnic, particular Judaism'. For proponents of this approach, a universal, non-ethnic view of Christianity amounts to a claim on superiority over particular, ethnic Judaism (Buell 2005:2; Concannon 2014:4; Horrell 2016:440, 459-460). In reaction to such a view of Christianity, it is argued that there is no dichotomy between natural, physical relationships and constructed, made-up relationships. Both kinship and ethnicity are viewed as social constructions (Johnson Hodge 2007:15-16).

Within the ethnic-reasoning position, there exists the tendency to view ethnicity as fluid and changeable (Buell 2005:7-10; Harrill 2014:380-381), and to view ethnicity as equivalent to or as including religion (Buell 2005:8-10; Fredriksen 2008:6-7, 2010:234-235; Harrill 2014:396; Horrell 2016:454; Johnson Hodge 2007:48). The category of religion, in turn, is normally understood as overlapping with a nation's culture, which includes their cultic and ritualistic practices (Harrill 2014:393-395; cf. Buell 2005:2-10, 45, 58, 62; Fredriksen 2010; Johnson Hodge 2007:20-22, 26-28, 54, 65).

The aim of this article is to broadly reconsider the compatibility of the concepts such as ethnicity, religion, culture, cult and ritual with the way in which mainly Paul presents the Christ-believing identity. Part of the aim is to determine how these concepts interact with the theological categories in which the Christ-believing identity is addressed in mainly the Pauline corpus. By using the term 'theological', the intention is not to imply that Paul or other New Testament authors were 'theologians' as such. It is rather used here in a limited sense as pointing to language that directly involves the human-divine relationship. Specific aspects that will constitute a focus in this discussion are the (1) concepts of ethnicity and religion in relation to Paul's theologising on identity, (2) the nature of believers' relation to Abraham and (3) the flesh versus S/spirit dichotomy in the Pauline literature. 


\section{Ethnicity and religion in contemporary scholarship in relation to Paul's theologising on identity}

The concept of ethnicity is currently much debated in scholarship, and the aim of this article is not to rehearse this debate in full here. The aim is rather to describe the kind of category that the concept represents. On the one end of the debate, proponents of the ethnic-reasoning position argue that early Christianity was an ethnos ${ }^{1}$ or that it significantly overlapped with the category of ethnos (e.g. Horrell 2016:458). On the other end of the debate, scholars such as Mason and Esler (2017:502) point out that ethnos was a stable and accepted category in antiquity that was mainly determined by origin and background (see Barth 1969:13), which included a common name, a myth of common ancestry, a shared history, a common culture, common customs, a link with a homeland and a sense of communal solidarity.

Hutchinson and Smith (1996:6-7), from whom Mason and Esler borrow these common denominators, also include 'religion' as being part of culture. But Mason (2007:481-488) argues that a full-scale religion as such is essentially a Western category with no counterpart in ancient culture, although ancient culture could incorporate 'religious' aspects. Although critiquing the ethnic-reasoning position, Mason and Esler (2017:504-505, 508, 511, 515) do not view early Christianity as universal or as inclusive, but rather as being in opposition to settled ethnos-polis life. For them, early Christianity was rather based on voluntary association, which was trans-ethnic and solely defined by a common devotion to Christ (Mason \& Esler 2017:507, 510-511, 515).

There is, however, a common denominator on both ends of the debate about ethnicity and related aspects. Ethnicity, race and culture can all be considered as anthropological phenomena. The term 'anthropological' is used here in a limited sense. It is used as it is normally used in theological discourse, as pertaining to human behaviour, experience and ability. Although anthropology in theological discourse usually pertains to the construction of a human person (e.g. Van Kooten 2008), in this article, that which is 'anthropological' is used in contrast to that which is 'theological'. The use of 'anthropological' here, however, does overlap with the traditional theological understanding of anthropology in that it involves the domain of what Paul describes as $\sigma \alpha \alpha \rho \xi$ ['flesh'] in certain contexts (see below). As will be argued, cultic practices, ritualistic customs and even religion could also be considered as resorting under the anthropological domain. Apart from the view that religion as such is a product of culture (e.g. Guthrie 2000:225-226; cf. Bowie 2006:12), it will be argued that phenomena such as ethnicity, religious rituals and/or cultic customs are even considered by the Apostle Paul as being within the anthropological domain, although he obviously does not frame them within modern or postmodern categories.

The best example where Paul refers to ethnicity as well as ritual and/or cultic practices is probably found in Romans 9:3-5. In verse 3, he addresses his kinsmen 'according to the

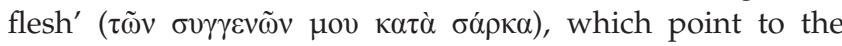
whole nation of Israel by natural, earthly descent (BDAG, s.v. $\sigma \alpha ́ \rho \xi$, §4), blood relationship and/or race (Zerwick \&

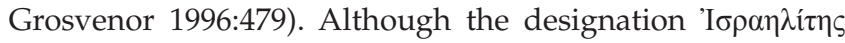
('Israelite') in verse 4 can be considered an insider term for the people of God (Dunn 1988b:526; Elliott 2007:123; Jewett 2007:562) of the Old Testament, the privileges of an 'I $\sigma \rho \alpha \eta \lambda i \tau \eta$ S that Paul lists in the subsequent verses (vv. 4-5) can all be understood as identity markers of the identity 'according to

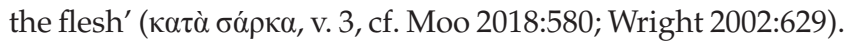

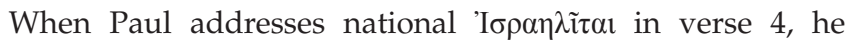
probably has historical Israelites in mind (Dunn 1988b:535; Käsemann 1980:258; Moo 2018:580; Munck 1967:30; Ridderbos 1959:207), ${ }^{2}$ although unbelieving Judaeans in his present would stand in continuity with them (Dunn 1988b:535). But more to the point, the eight privileges according to the flesh pertain to their national or ethnic identity. In fact, Paul specifically distinguishes these privileges from being part of true Israel in verse 6: 'for all

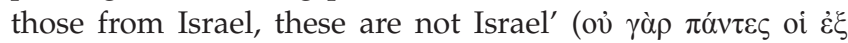

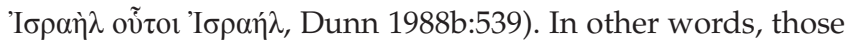
who were natural descendants of the patriarch Israel (BDAG, s.v. 'I $\sigma \rho \alpha \lambda^{\lambda} \lambda$, §1; Moo 2018:593) were not necessarily part of the true people of God. What we have in Paul's interpretation is thus two dimensions to the historical people: (1) national, ethnic Israel and (2) 'true Israel' within ethnic Israel (Moo 2018:595; Wright 2002:636). Cranfield (1979:481) states that those who constitute the latter (2) 'stand in a positive relationship to God's purpose', which differentiates them from those who 'stand outside the circle of the Israel within Israel' (1). Such a notion is confirmed by verses 7-8: 'not all of Abraham's children are his true descendants; but "It is through Isaac that descendants shall be named for you"' (NRSV). Those in Isaac represent God's people in the spiritual realm in contrast to those who are offspring in the physical realm (cf. Moo 2018:596; Gl 4:28).

The anthropological or natural mode of identity (according to the flesh) of national Israel also coheres with the effect that the eight privileges ( $\mathrm{Rm}$ 9:4-5) had on them. The adoption (vio $\theta \varepsilon \sigma^{\prime} \alpha$ ) has to mean something different from the adoption of believers in 8:15,23, where adoption is a result of receiving the Spirit and not something obtained by physically being part of a nation (Moo 2018:582-583; cf. Munck 1967:31).

Similarly, adoption according Galatians 4:5 coincides with the sending of God's son and his redemption of those under the law, which implies that such adoption was inaugurated at the Christ event. The adoption of Romans 9:4 thus 'conveys to that nation all the rights and privileges included within the

2.That historical Israel is in view here can be derived from third person ( Israelites are addressed (if Paul addressed Judaeans in his present, he probably would have used the second person), but especially from the fact that Paul elaborates on the history of Israel in vv. 9-17. 
Old Covenant' (Moo 2018:583) and does not necessarily entail salvation (Moo 2018; Osborne 2004:238). The glory $\left(\delta \xi^{\prime} \alpha\right)$ refers to God's presence with historical Israel and particularly the theophanies that were a privilege of Israel as God's national nation (e.g. Ex 16:10; 24:5-17; 40:34-35; Lv 9:23; Nm 14:10, Dunn 1988b:526, 534). ${ }^{3}$ It is not clear what the covenants ( $\delta 1 \alpha \theta \tilde{\eta} \kappa \alpha$ ) refer to, but they probably refer to the several covenants mentioned in the Hebrew Bible (Cranfield

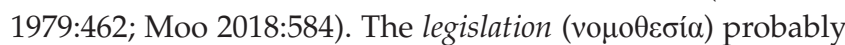
corresponds to the covenants and is thus equivalent to the law of Moses (Osborne 2004:239). ${ }^{4}$ The service ( $\left.\lambda \alpha \tau \rho \varepsilon i ́ \alpha\right)$ refers to national Israel's sacrificial system (Dunn 1988b:527; Käsemann 1980:259) 5 or cultus and not necessarily to their deeper worship such as their praying. It is likely that $\lambda \alpha \tau \rho \varepsilon i \alpha$ thus refers to their ritual acts of worship in general (cf. Jos 22:27; $1 \mathrm{Chr} 28: 13$ ) and the entire Yahwistic religious system (Hultgren 2011:358; Osborne 2004:239; 1 Macc 1:43; 2:19, 22). Yet, this ritual practice was not a barometer of the condition of people's hearts as such (cf. Is 1:13-14; 29:13; Mt 15:7-9; Mk 7:6). The promises ( $\dot{\varepsilon} \pi \alpha \gamma \varepsilon \lambda \lambda_{i \alpha 1}$ ) refer to the promises to the fathers (cf. غ̇ं $\alpha \gamma \gamma \varepsilon \lambda i \alpha \varsigma \tau \tilde{\omega} v \pi \alpha \tau \dot{\varepsilon} \rho \omega v$ in 15:8; Dunn 1988b: 528; Moo 2018:585). The fathers ( $\pi \alpha \tau \dot{\varepsilon} \rho \varepsilon \varsigma$ ) themselves are thus key to these promises, constituting the linchpin of salvation history (see esp. 9:6b-13; 11:15, 28; Moo 2018:585). Lastly,

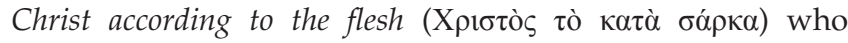
became Israel's Messiah is from ethnic Israel (Hultgren 2011:358; cf. Osborne 2004:240), which is the highest of all privileges (Dunn 1988b:528; Osborne 2004:240; Wright 2002:634). In summary, none of these privileges imply salvation or devoutness to God as such. That is not to say that privileges such as the glory or the promises did not involve divine intervention, but the point is that all of national Israel shared in these promises by default, that is, in terms of their natural or anthropological existence as a nation. In respect of their service, for example, one could participate in it without necessarily having a personal relationship with God. In other words, participation in rituals or cultic acts could merely be a social or 'external' endeavour. This is comparable to someone that is raised in a Christian family or a Christian church. Such a person may have participated in all the rituals or communal activities but would not necessarily be a devoted or saved Christian who has a personal relationship with God.

Within the context of the early Christian identity, a comparable principle is laid down in Colossians 2:16-23, ${ }^{6}$ where rituals or cultic practices such as food laws, feasts, new moons or Sabbaths are considered as unimportant shadows that pointed forward to the head, which is Christ (vv. 16-17). Even asceticism or false humility ( $\tau \alpha \pi \varepsilon 1 v o \varphi \rho \circ \sigma v ́ v \eta)$, the worship of angels or going into the detail ( $\dot{\varepsilon} \mu \beta \alpha \tau \varepsilon v ́ \omega$,

3.The glory that Paul has in mind here can be compared to the glory of the tempora ministry of Moses that was abolished (2 Cor 3:5-16).

4. Hultgren (2011:357) mentions 2 Maccabees 6:23, which refers to the law of Moses as 'the holy God-given law' and to 4 Maccabees 17:16, which refers to it as 'the divine legislation'. This interpretation would additionally correspond to Paul's later referral to the law (Rm 9:31, 32; 10:4, 5).

5.Moo (2018:584) points out that all nine occurrences of $\lambda \alpha$ tpei $\alpha$ in the Septuagint carry this notion.

6.Although Colossians is here regarded as Pauline, it is not a prerequisite that the letter has to be written by Paul for the sake of the argument in this article.
BDAG, s.v. $\dot{\varepsilon} \mu \beta \alpha \tau \varepsilon v ́ \omega, \S 3)^{7}$ of visions are considered as insignificant and in fact considered a distraction (v. 18) away from Christ (v. 19). Grundmann (1972:22) points out that $\tau \alpha \pi \varepsilon$ vофроби́vๆ (v. 18) 'denotes cultic practice rather than a disposition'. In the same vein, regulations ( $\left.\delta 1 \delta \alpha \sigma \kappa \alpha \lambda i \alpha^{\alpha}\right)$ about not touching, tasting or handling things (vv. 20-21), which probably should be read 'within a general framework of cultic concerns' (Pao 2012:195), are also considered as a distraction (v. 20). Significantly, in verses 22-23, these things are considered as 'according to human commandments and

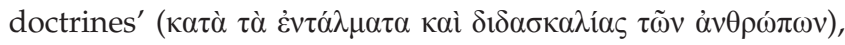
which 'have indeed an appearance of wisdom in

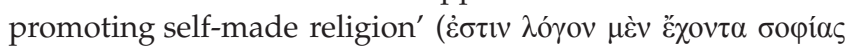

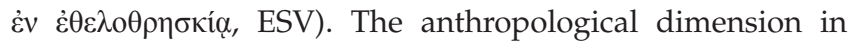
which these practices occur is thus evident. Although in this context, $\dot{\varepsilon} \theta \varepsilon \lambda \circ \theta \rho \eta \sigma \kappa i ́ \alpha$ probably points to 'religious achievements' that are 'taken on voluntarily, which are generally considered wise, but in reality have no value and only satisfy the carnal attitude', in principle, constructions with $\dot{\varepsilon} \theta \varepsilon \lambda \mathrm{o-}^{-}$'can be used to express an intent in a positive or critical manner' (Balz 1990:381). In other words, it could be possible that all kinds of voluntary religious actions are considered as human-made and thus as a distraction away from Christ. Nevertheless, the passage concludes that the kind of religious acts that are described in 2:16-23 is considered as being 'of no value against the indulgence of the flesh' (ой

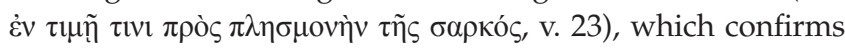
the anthropological dimension in which these acts occur.

In terms of the context of Colossians, human action in religious acts in Colossians 2:16-23 is contrasted with divine action in 3:1-4, which speaks of being raised with Christ (v. 1), the things above (v. 2), believers' death in Christ (v. 3) and, probably most importantly, Christ who is believers' life

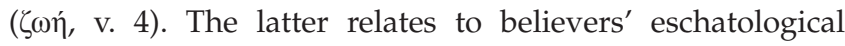
identity that is rooted in the work and the person of Christ (Moo 2008:251-252; Wright 1986:137; cf. Gl 2:20). In James Dunn's (1996:208) words, the reference to Christ being 'your life' is a way of 'emphasizing the centrality of Christ for believers', which points to 'everything which gives the Christian meaning and identity'. It could thus be concluded that according to Colossians 2:16-3:4, the early Christian identity is not defined by religious or ritual actions, but by the work and the life of Christ himself. In other words, the identity in Christ is not rooted in an anthropological reality, which includes acts of religion, but in a theological reality, which points to God's actions. ${ }^{8}$

Similar notions to those found in Colossians 2:16-3:4 are found in Galatians 4:9-19 and Romans 14:1-15:2.

In Galatians 4, Paul refers to the observance of days, months, seasons and years (v. 10) as being part of 'weak and worthless

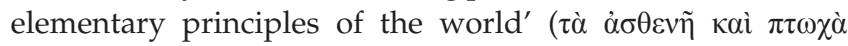

7.Being a hapax legomenon, the meaning of $x \mu \beta \alpha \tau \varepsilon v \omega$ is unclear. It could also point to

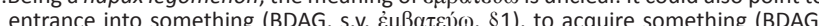
s.v. $\dot{\varepsilon} \mu \beta \alpha \tau \varepsilon v \omega, \S 2$ ) or even to come into possession of something (Wilson 2005:223).

8.The same principle lies behind Colossians 2:17, which contrasts the external, ritual acts of human beings with the 'substance' (NRSV; ESV) or the 'reality' (BDAG, s.v. $\sigma \tilde{\omega} \mu \alpha, \S 4 ; \mathrm{REB} ; \mathrm{NIV})$ constituted by Christ, which, in turn, points to an identity in Christ by implication. 


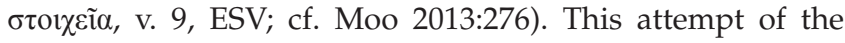
Galatian church to return to these outward, religious practices, whether they merely represent Judaean practices or (include) gentile practices, causes Paul to say that he laboured over the congregation in vain (v. 11). Within the wider context of Paul's argument in Galatians, the deeper notion behind Paul's anguish is arguably that these outward religious practices work against the formation of Christ in them (v. 19). In other words, these things are a distraction away from the main focus, which is Christ. In Romans 14:1-15:2, Paul probably addresses a situation where certain Judaean believers took exception to the nonobservance of certain religious practices by gentile believers (cf. Longenecker 2016:995-996; Moo 2018:845; Schreiner 2018:691-692). The religious practices at stake pertain to the abstention from certain foods and from wine, which the Judaean believers considered as impure, and the observance of certain days, which they considered as holy. But Paul considers the Judaean believers' insistence on these religious practices as weakness in their faith $(14: 1-2,21 ; 15: 1$; Gagnon 2000). These religious practices are considered as a distraction away from the 'kingdom of God', which is about 'righteousness and peace and joy in the Holy Spirit' (14:17), and about the serving of Christ in these things (14:18). Again, the focus is drawn away from the anthropological and the material to the theological and the spiritual.

A comparable notion about acts of religion is presented in James 1:27. The author writes about pure and undefiled 'religion' ( $\theta \rho \eta \sigma \kappa \varepsilon i ́ \alpha)$, which entails the visitation of orphans and widows in their affliction and the keeping of oneself unstained or unpolluted from the world. In this context, religion has more to do with the right human conduct (McKnight 2011:172) or the human ethical behaviour (cf. McCartney 2009:131) that is expected of a believer than it denotes one's status or one's identity before God. Although applied in a positive context, religion in James can, thus, also be considered as more anthropological than theological. ${ }^{9}$

Lastly, it could be asked if baptism itself must be understood as a cultic ritual that inaugurates people into a material family, as Johnson Hodge (2007:41, 67, 76-77) argues. The problem with such an approach is that Paul never explicitly states that an actual 'transformation... takes place during baptism'. ${ }^{10}$ But contrary to what Johnson Hodge (2007:76) asserts, such a notion is not clear from Galatians 3:26-29. The transformation and the new identity in Christ (being 'sons' of Abraham or 'sons' of God) are established through faith (Gl 3:7, 26) rather than through baptism as such. Baptism indeed involves the active appropriation and the acting out of one's new found identity by 'clothing oneself'

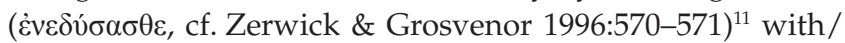

9.See also the description in 2 Timothy $3: 5$ of people in the last days who have "the

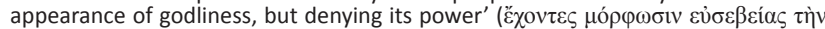

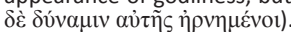

10.Johnson Hodge (2007:76) argues that such a notion is implicit to Romans 8:14-17 and Galatians $4: 1-7$, but these passages do not mention baptism as such, but rather point to the work of the Spirit in believers (see below).

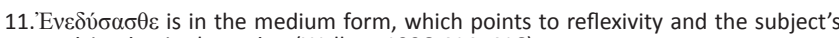
participation in the action (Wallace 1996:414-416) in Christ (v. 27). But Paul's language is rather 'a metaphor drawn from the rite of baptism to describe the entry of a believer into Christian experience', or more specific, to describe 'the entry of the believer into the spiritual relationship of the Christian with Christ, which takes place in conversion initiation' (Dunn 1970:109). Similarly, Fung (1988:174) describes baptism according to Galatians 3:27 as the 'outward and visible sign of inward and spiritual grace'. In other words, although baptism is closely associated with spiritual transformation in Paul (cf. Rm 6:3-4), it is not baptism itself that brings about the transformation, but the dying and crucifixion with Christ that brings about transformation (cf. Dunn 1988a: 314; Osborne 2004:152).

The other text that Johnson Hodge (2007:76) quotes in support of the notion that baptism itself brings one into the Christian family is 1 Corinthians 12:13. But it is questionable whether Paul's reference to baptism by or in one Spirit ( $\dot{\varepsilon} \vee \dot{\varepsilon} v i$ $\pi v \varepsilon u ́ \mu \alpha \tau 1)$ refers to water baptism or that it speaks of transformation that takes place during baptism, as Johnson Hodge implies. ${ }^{12}$ The two main clauses in this verse are (1) 'in

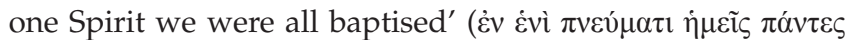
$\grave{\varepsilon} \beta \alpha \pi \tau i ́ \sigma \theta \eta \mu \varepsilon v)$ and (2) 'were made to drink of one Spirit'

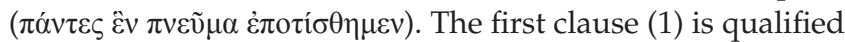
by the prepositional phrase 'into one body' ( which, in turn, is modified by the parenthetical phrase

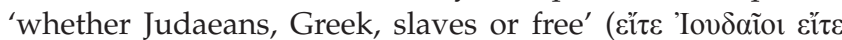

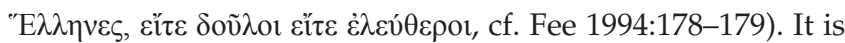
very likely that the two clauses (1 and 2 ) constitute a Semitic parallelism wherein both clauses carry the same notion (Fee 1994:180; adopted by Ciampa \& Rosner 2010:592), which is a common device in Paul (1 Cor 12:15-16, 17, 21, 22-3; 10:23). This view argues strongly for a metaphorical understanding of 'baptism' in the first clause (1)..$^{13}$ The second clause, thus, hardly points to Spirit baptism, the Lord's Supper or to confirmation, $^{14}$ but rather points to the congregation's conversion and their receiving of the Spirit (Dunn 1970:130; Fee 1994:181; Kistemaker 1993:430), accompanied by the demonstration of the Spirit and of power (1 Cor 2:4), which is the true beginning of the new identity in Christ (G1 3:2-5). In reference to 1 Corinthians 12:13, Ben Witherington (1998:276) rightly states that it 'is the Spirit, not water baptism that joins a person to the body of Christ'. In Romans 8:16, Paul states that the Spirit witnesses with the believers' spirit that they are 'children' ( $\tau \dot{\varepsilon} \kappa v \alpha)$ of God (cf. Gl 4:6). Without the inward renewal of the Spirit in people's lives, the true mark of identity in the New Covenant (Fee 1994:383, 469-470, 553; Hays 2000:251; Hansen 2009:221; Moo 2013:182) is wanting. ${ }^{15}$ Rather than constituting a rite of passage into the Christian community, baptism can thus be understood as social, human enactment and confession of the incorporation into God's family by the Spirit (cf. Witherington 1998:276-277).

12.Johnson Hodge (2007:76) argues that this 'baptism passage' specifically speaks of 'receiving the spirit', which is circular reasoning.

13.Paul applies 'baptism' in a metaphorical sense in 1 Corinthians 10:2 (Dunn 1970:129).

14.For a discussion of these views, see Fee 1994:180

15.See Galatians 3:14, in which the Spirit is pictured as the actual fulfilment of the promise to Abraham. 


\section{The nature of believers' relation to Abraham}

The contention from the side of the ethnic-reasoning position is that Paul's linking of Christ believers with the patriarch Abraham is essentially an ethnic or kinship connection (Buell 2005:106; Horrell 2016:445; Johnson Hodge 2007:21, 42, 79-107; Sechrest 2009:113-133). The question is, however, if such a conclusion can be derived from the way in which Paul describes believers' relation to Abraham. According to Galatians 3, the early Christians' only connection point to Abraham was faith in Christ. ${ }^{16}$ In verses 6-7, Paul reasons that just as Abraham was counted as righteous on the basis of

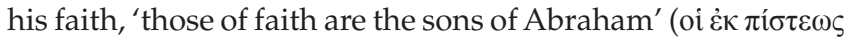

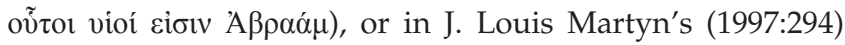
translation, 'those whose identity is derived from faith, these are the children of Abraham'. Although the promise (Gn 12:3) entailed that the nations would be blessed in Abraham (G1 3:8), it does not necessarily follow that the nations would be considered as Abraham's ethnic kin. In fact, Paul is at pains to accentuate that the 'seed' $(\sigma \pi \varepsilon \dot{\varepsilon} \rho \alpha)$ of Abraham is singular and refers to Christ as only 'seed' of the promise (Gl 3:16). Yet, Christ indeed had a physical and ethnic connection with Abraham, for he was born in the lineage of David and part of the nation of Israel 'according to the flesh' (Rm 1:3; 9:5). On Paul's logic in Galatians, believers do not share in this lineage 'according to the flesh'. Their connection with Abraham is rather on the basis of faith $(\mathrm{Gl} 3: 7,9)$, that is, not on the basis of 'flesh' $(3: 3 ; 4: 23,29)$ but on the basis of the 'Spirit' (3:3, 14; 4:6, 29).

In other words, believers do not connect to Abraham through the nation of Israel as such, but through Christ only. By belonging to Christ, believers are indeed now considered as Abraham's 'sons' (3:7) or Abraham's 'seed' (3:29), but they do not become fictive kin of the nation of Israel as such. They only share in the blessing to Abraham (3:8-9) and the inheritance promised to him (3:29) through their connection with Christ. ${ }^{17}$

In Paul's exposition of believers' identity in relation to Abraham and Christ, the non-ethnic or non-racial nature of Paul's language in Galatians 3 is accentuated by the way in which Paul exchanges 'sons of Abraham' (v. 7) with 'sons of God' (v. 26). This is what is truly meant by being 'sons of Abraham', for language about direct filiation to God is actually the more dominant language in Paul. ${ }^{18}$ Through faith, people

\footnotetext{
16.That Paul includes Judaean believers in his rhetoric can be derived from his use of the first person singular and plural in the letter, which includes himself, a Judaean believer $(1: 4,2: 4,5,15,16,17,19-21 ; 3: 13,14,23-25 ; 4: 3,5,6,26,28,31 ; 5: 1,5,25)$.

17.It is noteworthy that Paul keeps using the singular form 'seed' ( $\sigma \pi \varepsilon p \mu \alpha)$ in Galatians 3:29 in his reference to believers, which identifies them with Christ as single seed (v. 16). Christ is their only connection point to Abraham. They are connected to Abraham in as far as they share in the identity in Christ. In other words, they do not become new 'seeds' of Abraham as such, but derive their indirect relation to Abraham from their connection with Christ.

18.See Paul's references to 'sons' (vioí) of God (Rm 8:14, 19; 9:26; GI 3:26; 4:6), 'children' ( $\tau \varepsilon \dot{\kappa} v \alpha)$ of God (Rm 8:16, 17, 21; 9:8; Phlp 2:15; cf. Eph 5:1) and 'heirs'

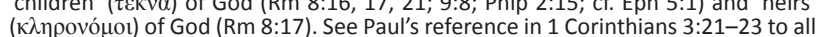
things (including the world, life, death, the present and the future) that belong to believers, who are Christ's, and Christ who are God's. See also Paul's language believers, who are Christ's, and Christ who are God's. See also Paul's language
about believers being part of the 'body' $(\sigma \tilde{\omega} \mu \alpha)$ of Christ as head of the body about believers being part of the 'body
}

become God's new spiritual family, which can hardly be described in ethnic or racial terms (cf. Fung 1988:138; George 1994:223-224; Ryken 2005:99). In contrast with Paul's opponents' probable claim on physical circumcision (Fung 1988:138; Longenecker 1990:114; Moo 2013:192), the spiritual nature of God's family is further emphasised. Being God's offspring is thus the all-important point Paul wants to make here rather than being offspring of Abraham as such (cf. Martyn 1997:306). In fact, the reference to believers being the 'sons' or 'seed' of Abraham in Galatians 3:7, 29 and even the reference to Abraham being 'the father of us all' ( $\pi \alpha \tau \eta$ $\pi \alpha ́ v \tau \omega \nu$ i $\mu \tilde{\omega} v)$ in Romans 4:16 refer in context to believers' connection with Abraham in terms of their faith in Christ: just as Abraham believed and it was counted to him as righteousness, believers in Christ are also now counted as righteous on the basis of their faith (cf. Betz 1979:142). Believers are thus 'sons' of Abraham in that they are modelled on Abraham's faith rather than they became (ethnic) offspring or fictive kin of him. Such a usage of 'sons of' would correspond with a Semitic usage, which would denote 'share in a particular quality or characteristic' (Dunn 1993:162). For example, Paul also uses 'sons of' in the constructions 'sons of

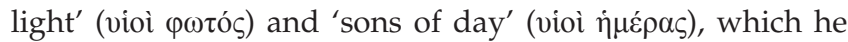
contrasts with being of night and of darkness (1 Th 5:5). Similarly, in Ephesians 2:2; 5:6 and Colossians 3:6, 'sons of' is used in the negative construction, 'sons of disobedience' (vioù $\tau \tilde{\eta} \varsigma \dot{\alpha} \pi \varepsilon 1 \theta \varepsilon i ́ \alpha \varsigma)$, which pertains to a negative character. Yet, in context of Galatians 3, believers also share in the promise and the blessing to Abraham. The reference to being 'sons' of Abraham thus also functions as a 'metaphor of inheritance' (Jervis 1999:86). In Paul, believers' relationship to Abraham can thus hardly be expressed in material, physical or ethnic terms.

Such a view on the kind of relationship that believers have with Abraham is also anticipated in the Synoptic Gospels, where John the Baptist in his quarrel with the Pharisees says that God is able to raise up children of Abraham from stones (Mt 3:9; Lk 3:8), which is associated with the bearing of good fruit (Mt 3:10; Lk 3:8).

In the Fourth Gospel, Jesus repeats the same thought when he connects being children of Abraham with the doing of the works of Abraham (Jn 8:39). Being children of Abraham is thus disconnected from biological or ethnic descent and associated with people's spiritual quality, which, according to John the Baptist, originates from a creative act of God. ${ }^{19}$

\section{The flesh versus Spirit dichotomy in Paul}

As ethnic-reasoning proponent, Johnson Hodge (2007:74) views the 'spirit' $(\pi v \varepsilon \tilde{v} \mu \alpha)$ as something that 'establishes an ethnic or kinship tie with God'. In reference to Hellenistic, philosophical, medical texts, she applies their material view of $\pi v \varepsilon \tilde{u} \mu \alpha$ to Paul (Johnson Hodge 2007:74-75). She sees $\pi v \varepsilon \tilde{v} \mu \alpha$ in Paul as a 'material' version of 'shared blood' that 19.The latter notion can further be derived from John's reference to repentance and the baptism of the Holy Spirit (Mt 3:11; Lk 3:16). 
'provides a tangible, organic connection between Christ and the gentiles'. She contends that by 'the incorporation of Christ's spirit in their bodies, the gentiles inherit his ancestry' (Johnson Hodge 2007:76). Apart from the question about the legitimacy of applying these Hellenistic categories to Paul, it is another question if Paul's theological reflection about 'flesh' ( $\sigma \alpha \dot{\rho} \xi)$ versus 'S/spirit' ( $\pi v \varepsilon \tilde{v} \mu \alpha)$ can be harmonised with her contentions.

The dichotomy between $\sigma \alpha \dot{\rho} \xi$ and $\pi v \varepsilon v \tilde{\mu} \alpha$ is probably one of the most prominent contrasts in Paul. Both the terms бó $\rho \xi$ and $\pi v \varepsilon \tilde{v} \mu \alpha$ are used within a wide semantic range in Paul, which makes it quite challenging to grasp all the various nuances around these terms and their cognates. In a broad sense, $\sigma \alpha ́ p \xi$ can denote physical flesh (e.g. 1 Cor 15:39), the human body (1 Cor 6:16), a human being (e.g. 1 Cor 15:39; BDAG, s.v. $\sigma \alpha ́ \rho \xi, \S 1-3 ;$ L\&N, §8.63; 8.4; 9.11), human or

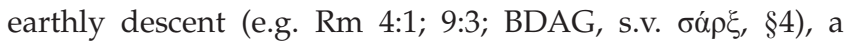
nation (e.g. Rm 11:14; L\&N, §10.1), ${ }^{20}$ physical human nature (e.g. Gl 4:23 - pointing to natural human birth; L\&N, §58.10) and psychological human nature (e.g. 1 Cor 1:26 - as opposed to God's Spirit; L\&N, §26.7). It is noteworthy that the category of $\sigma \alpha \dot{\rho} \rho \xi$ never transcends the anthropological sphere. In contrast, $\pi v \varepsilon \tilde{v} \mu \alpha$ can denote the Spirit of God (e.g. Rm 5:5; BDAG, s.v. $\pi v \varepsilon \tilde{u} \mu \alpha, \S 5 ; \S 8)$, the activity of God's Spirit in the believing community (e.g. 1 Cor 2:4; BDAG, s.v. $\pi v \varepsilon v \tilde{\mu} \alpha, \S 6$ ), a spirit which is not from God (2 Cor 11:4; BDAG, s.v. $\pi v \varepsilon v \tilde{\mu} \alpha$, $\S 7)$ and the 'non-material, psychological faculty' of human beings that is 'potentially sensitive and responsive to God' (L\&N, §26.9; cf. BDAG, s.v. $\pi v \varepsilon \tilde{v} \mu \alpha, \S 3$; cf. 1 Cor 5:3-5).

Yet, apart from these basic meanings of $\sigma \alpha \dot{\rho} \xi \xi$ and $\pi v \varepsilon v \tilde{\mu} \alpha$, Paul also uses them in an extended, metaphorical sense, where they indicate two distinct eschatological realities. Each of these two eschatological realities represents two distinct modes of identity.

The best example of this extended, eschatological use of $\sigma \alpha ́ p \xi$ and $\pi v \varepsilon \tilde{v} \mu \alpha$ in Paul is probably found in Romans 7:5-6. In this passage, 'flesh' denotes a past (ö $\tau \varepsilon . . . \tilde{\eta} \mu \varepsilon v$ ) mode of existence under law, sin and death (v. 5). Verse 6 states the contrast to the previous reality: 'but now we are released from the law' (vvvi

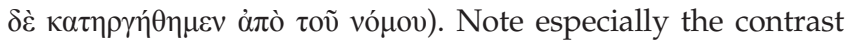
between the ö $\tau \varepsilon$ of verse 5 and the vvví of verse 6 . Believers have died to the law that held them captive, so that they 'now'

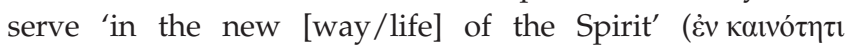
$\pi v \varepsilon v ́ \mu \alpha \tau o \varsigma)$ and not in the 'old [way of the] written code'

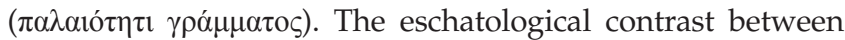
these two modes of existence is supported by several commentators (e.g. Cranfield 1975:337, 340; Fee 1994:504, 821; Jewett 2007:436-437; Käsemann 1980:190, 210; Longenecker 2016:636-637; Moo 2018:447; Osborne 2004:173;

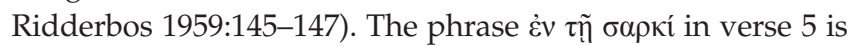
thus an indication of a way of existence outside of Christ and the Spirit (Fee 1994:510-511; Ridderbos 1959:145), and points to the human existence as a 'supra-individual reality to which the individual human-being-outside-of-Christ has lapsed 20.This meaning is incorporated under $\$ 4$ in BDAG. into' (Ridderbos 1959:145). ${ }^{21}$ Or in Fee's words, 'both the Law and the flesh belong to the past, on the pre-Christ, pre-Spirit side of eschatological realities' (Fee 1994:504). Similarly, $\pi v \varepsilon v \tilde{\mu} \alpha$ in verse 6 denotes the new way of existence and eschatological reality in Christ, of which the existence under the rule of God's Spirit has superseded the era under law, sin and death (cf. Fee 1994:507; Käsemann 1980:210). Because the Spirit marks the new identity in Christ (see above) and an existence in 'flesh' points to an identity outside of the Spirit, 'flesh' and 'S/spirit' in Romans 7:5-6 can thus be understood as each representing two distinct modes of identity. In this understanding, $\pi v \varepsilon v \tilde{\mu} \alpha$ does not point to God's Spirit as such, but to a mode of existence and identity where God's Spirit bears witness with the human spirit that the human person is God's child (Rm 8:16). In other words, $\pi v \varepsilon v \tilde{\mu} \alpha$ could include both God's Spirit and the human spirit that is 'sensitive and responsive to God' (dard practice in New Testament scholarship, §26.9).

Two other passages in Paul where the same kind of contrast between $\sigma \alpha ́ \rho \xi$ and $\pi v \varepsilon v \tilde{\mu} \mu$ is at play are Romans 8:1-16 and Galatians 5:16-25. In Romans 8, the 'now' (võv, v. 1) denotes the new era of salvation history that was inaugurated by Christ's death and resurrection (Longenecker 2016:684; Moo 2018:495). Another indicator in the text that two exclusive eschatological modes of identity are indicated by $\sigma \alpha ́ p \xi$ and $\pi v \varepsilon \tilde{v} \mu \alpha$ is the fact that believers in Christ are portrayed as not being 'in the flesh' any more (v. 9). In other words, living in or according to 'flesh' indicates an old mode of identity outside of Christ under the rule of law, sin and death, whereas living in or according to 'S/spirit' points to a new eschatological mode of identity under the freedom of God's Spirit (cf. Fee 1994:521-564; Jewett 2007:486; Moo 2018:499-501, 508; Käsemann 1980:212-213, 219-220; Ridderbos 1959:174-180). In Galatians 4:4-5, the dawn of the new eschatological mode

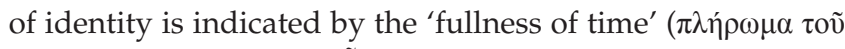

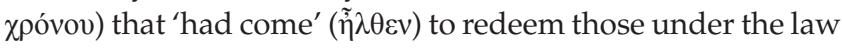

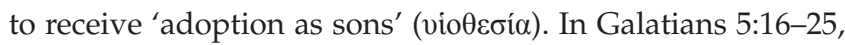
being led by the Spirit is simultaneously contrasted with 'flesh' (vv. 16-19, 24) and being 'under the law' (v. 18), which both refer to the identity outside or before Christ (cf. Bruce 1982:256; Fee 1994:438). In verse 19-21, the 'works of the flesh' are described in terms of not inheriting the kingdom (21), making such a mode of existence absolute. In other words, whether one inherits the kingdom or not pertains to being a believer or not (Fee 1994:431, 443). Verse 24 describes someone belonging to Christ as having crucified the 'flesh', which indicates the new identity in Christ over against the former way of life to which the 'I', the former self and the former identity, has died to (Gl 2:19-20). ${ }^{22}$ Christ and the Spirit thus mark the eschatological turning of ages, which corresponds with the new identity signified by faith (G13:7,9, 23, 25) and the Spirit (Gl 3:3, 14; 5:25; cf. esp. Ridderbos 1966:298-299; Fee 1994:427-458; Silva 2001:181-183).

An important factor in considering the two mutually exclusive identities in Paul that are represented by $\sigma \alpha ́ \rho \xi$ and 21.My own translation.

22.See also the eschatological võv in Galatians 2:20. 
$\pi v \varepsilon \tilde{u} \mu \alpha$, respectively, is that the mode of identity denoted by $\pi v \varepsilon \tilde{v} \mu \alpha$ is essentially within a divine sphere, whereas the mode of identity denoted by $\sigma \alpha ́ \rho \xi$ is essentially within a human sphere. Or in different terms, an identity according to $\pi v \varepsilon \tilde{u} \mu \alpha$ denotes an identity derived from the indwelling Spirit of God (Rm 8:9, 11).

This identity is accomplished by the Spirit of life that has set believers free from the law of sin and death ( $R m$ 8:2), by

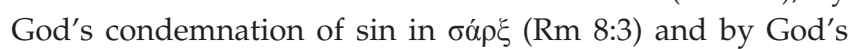
fulfilment of the right(eous) requirement of the law (Rm 8:4). None of the latter is within the sphere of human possibility. In contrast, an identity according to $\sigma \alpha \dot{\alpha} \rho \xi$ is derived from being under the obligation to do the whole law (Gl 3:10; Rm $8: 7)$, but with the inability to adhere to the law ( $\operatorname{Rm} 7: 18 ; 8: 3)$. It is noteworthy that when Paul in Romans 7:18 writes about $\sigma \alpha ́ \rho \xi$, he states that nothing good dwells 'in me, that is in my

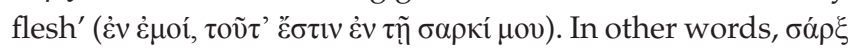
points to the sphere of humanness and human possibility.

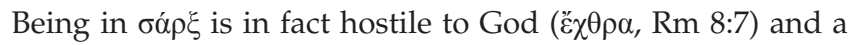
mode of identity that is unable to please God ( $\mathrm{Rm} 8: 8)$.

As pointed out above, another important connotation to $\sigma \alpha ́ \rho \xi$ is that it could pertain to natural, human descent (BDAG, s.v. $\sigma \alpha ́ \rho \xi$, §4). When Paul in Galatians 4:23, 29 refers to the son of the slave woman who was born 'according to the flesh'

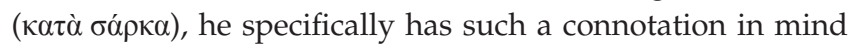
(De Boer 2011:292, 306; Moo 2013:299, 309). In other words, Paul expresses the contrast between the son of the slave woman, born according to the flesh (vv. 23, 29), and the son of the free woman, born according to the Spirit (v. 29), in terms of the human versus the divine. The child of the slave woman is born on the basis of human possibility or human will, whereas the child of the free woman was born on the basis of God's promise, which signifies divine intervention. Yet, the category of natural, human descent would include the category of ethnicity (cf. Garlington 2003:136). Such a connotation is especially evident in Romans 1:3 and 9:5, where Christ is presented as being from a specific ethnic lineage. A similar connotation is identifiable in Romans 4:1 where Abraham is considered the Judaeans' 'father according to the flesh', that is, their ethnic father, or in Romans 9:3 where Paul refers to his kinsmen 'according to the flesh' (cf. Rm 11:14; 2 Cor 11:18). Another instance where the connotation of ethnicity arguably forms part of the meaning of $\sigma \alpha \dot{\rho} \xi \xi$ is in 2 Corinthians 5.16, where Paul states that believers do not know Christ or anyone else 'according to the flesh' any more. ${ }^{23}$ Such a connotation is conceivable if it can be understood as a kind of reaction against the kind of credentials that Paul's opponents listed in the boasting about their identity (2 Cor 11:22) 'according to the flesh' (2 Cor 11:18).

From the $\sigma \alpha \dot{\rho} \xi / \pi v \varepsilon \tilde{u} \mu \alpha$ dichotomy in Paul, it can thus be derived that the category of $\sigma \alpha \dot{\rho} \xi \xi$ in its extended sense remains within the sphere of natural humanness and human possibility, which includes notions about human descent 23.See Barnett's (1997:296) reference to knowing Christ as 'a merely Jewish Jesus'. or ethnicity. In contrast, the category of $\pi v \varepsilon \tilde{u} \mu \alpha$ represents a divine category that originates from God's Spirit and transcends natural humanness or human possibility. Even the human spirit, which could be denoted by $\pi v \varepsilon v \tilde{\mu} \alpha$, points to its (potential) connection with God's Spirit. ${ }^{24}$ One could thus say that $\pi v \varepsilon \tilde{v} \mu \alpha$ in its extended application in Paul represents an identity which is based on that which is not natural and thus not physical or material, ${ }^{25}$ which would exclude categories such as human kinship or ethnicity.

Such a contrast is also evident in 1 Corinthians 2:13-15, where the 'spiritual' ( $\pi v \varepsilon v \mu \alpha \tau$ isós) is contrasted with that which is 'human' ( $\alpha v \theta \rho \omega \pi i v \eta \varsigma)$ and 'natural' ( $\psi v \chi \imath \kappa o ́ s)$. Filiation to God through the Spirit is thus of a different order than that which is designated with the category of ethnicity, even if ethnicity is defined such as that it includes religiousness.

In the Fourth Gospel, the $\sigma \alpha \dot{\rho} \xi / \pi v \varepsilon v \tilde{\mu} \alpha$ dichotomy is comparable with that in Paul. In the Gospel of John, these concepts are presented as two mutually exclusive ways of existence or sources of origin, where $\sigma \alpha ́ p \xi$ pertains to that which is natural or human, and $\pi v \varepsilon \tilde{v} \mu \alpha$ pertains to that which comes from God (Ridderbos 1997:131; cf. Carson 1991:196-197). This is the kind of meaning conveyed by Christ who was not born of the will of the 'flesh' or the will of a 'man', but of God (1:13). According to 3:3, only a person born 'from above' or 'again' (ö $v \omega \theta \varepsilon v$ ) can enter the kingdom, for 'what is born of the flesh is flesh, and what is born of the Spirit is spirit' (3:6). Birth 'of the flesh' thus points to natural birth and the mode of existence of the natural human person (Bruce 1983:85; Carson 1991:196; Ridderbos 1997:128). Вy implication, any claim on God's kingdom on the basis of things such as nationality, ethnicity or even religious tradition (all pertaining to natural existence) cannot assure entrance into God's kingdom. Every person, irrespective of ethnicity, has to receive the Spirit as 'eschatological gift' (Ridderbos 1997:127; cf. Bruce 1983:110; Carson 1991:224-225).

\section{Conclusion}

It is far from settled whether the concept of ethnos should include the concept of 'religion'. But even if it would, religious aspects as portrayed in the New Testament have to be distinguished from what is understood under 'religion' within a contemporary, Western context. Notwithstanding the latter distinction, it has been argued that the religious, the ritualistic and the cultic can all be considered as anthropological phenomena in Paul, which means that they pertain to human conduct and human possibility. From Romans 9:4-5, it has been argued that national, ethnic Israel did also share in the eight privileges (adoption, glory, covenants, legislation, service, promises,

24.See esp. Romans 8:16, where the human spirit stands in a direct relation to God's Spirit.

25.This does not imply that the newly expected eschatological 'spiritual body' ( $\sigma \tilde{\omega} \mu \alpha$

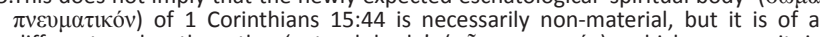
different order than the 'natural body' ( $\sigma \tilde{\omega} \mu \alpha$ uvolikóv), which means it is

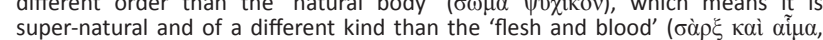
1 Cor 15:50) of natural human beings (cf. Thiselton 2000:1275). It is thus a body 1 Cor 15:50) of natural human beings (cf. Thiselton 2000:1275). It is thus a body
that is animated by God's Spirit. But the Spirit himself, who creates the new identity in Christ, can hardly be confined to the category of the natural or the material. 
fathers and Christ according to the flesh) without necessarily having a personal relationship with God. In other words, these rituals or cultic acts could merely be a social or external endeavour without being constitutive of the 'true' or 'inner' Israel of the Old Testament. Similarly, the way in which Colossians 2:16-23 refers to rituals or cultic practices such as food laws, feasts, new moons or Sabbaths can be considered as denoting human actions (anthropological) that are not constitutive of the in-Christ identity. In the same vein, the religious practices portrayed in Galatians 4:9-19 and Romans 14:1-15:2 are considered by Paul as a distraction away from Christ and God's kingdom. In Paul, the in-Christ identity is portrayed as not being an anthropological reality, but as a theological reality, which points to God's work in Christ, who provides believers with life and identity. The reference to 'religion'

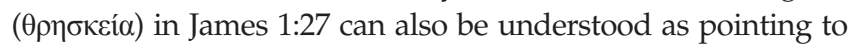
human conduct or human ethical behaviour, without being constitutive of one's status or identity before God. While Christian baptism is understood by Johnson Hodge as a ritual of entrance into a material family, baptism is rather to be understood as a symbolic enactment and confession of the incorporation into God's family on the basis of the work of the Spirit. In other words, the entry point to the believing community is not baptism as such, but the work of the Holy Spirit.

In terms of the way in which Paul portrays believers' relation to Abraham, it has been argued that such a connection is neither material nor ethnic, but based on direct filiation to God in Christ, which is the more prevalent imagery of filiation in Paul. Their connection to Abraham is through Christ as single 'seed' of the promise. They are 'sons of' Abraham in that they model Abraham's faith rather than becoming actual (ethnic) offspring of Abraham. Their filiation to Abraham is thus spiritual rather than ethnic or material.

As for the $\sigma \alpha \dot{\rho} \xi-\pi v \varepsilon v \tilde{\mu} \alpha$ dichotomy in Paul, when Paul uses these opposites in an extended meaning such as is identifiable in Romans 7:5-6; 8:1-16 and Galatians 5:16-15, they indicate two exclusive modes of existence and identity on either side of the Christ event or inside and outside the in-Christ identity. In these contexts, $\sigma \alpha \alpha \rho \xi$ points to an identity outside of Christ under the law, sin and death, which is confined to human possibility, but which is inadequate and unable to establish a right relationship with God. The human sphere to which the concept of $\sigma \alpha ́ \rho \xi$ points includes things such as natural, human descent, ethnicity and even religious acts. In contrast, $\pi v \varepsilon \tilde{u} \mu \alpha$ points to an identity in Christ derived from the indwelling Spirit and the salvific power of the Spirit in freeing believers from the $\sigma \alpha \dot{\rho} \xi$-identity. At heart, the $\sigma \alpha \dot{\rho} \xi-\pi v \varepsilon v \tilde{\mu} \alpha$ dichotomy can thus be understood as a contrast between human possibility and divine possibility. The human versus divine dichotomy as an essential referent of the $\sigma \alpha ́ \rho \xi-\pi v \varepsilon \tilde{v} \mu \alpha$ dichotomy is echoed by the Fourth Gospel, where $\sigma \alpha \dot{\rho} \xi$ points to an identity which is natural or human and $\pi v \varepsilon \tilde{v} \mu \alpha$ points to the divine origin of identity.

In summary, according to the theological categories in which Paul portrays the identities inside and outside of
Christ, the religious, the cultic and the ritualistic can all be considered as anthropological and thus as within the sphere of human possibility. All of these can be considered as within the sphere of $\sigma \alpha \dot{\rho} \rho \xi$ and thus as non-constitutive of the new identity in Christ. The new identity in Christ is rather an identity derived directly from God's Spirit, which transcends the anthropological sphere. The new identity in Christ is thus portrayed by Paul as essentially trans-ethnic and trans-religious. In terms of origin, the in-Christ identity has a non-human, non-natural, non-material and even a non-social origin. This does not mean that the in-Christ identity does not have a social dimension or that social formation theory is inappropriate in studying identity in the New Testament, but that the in-Christ identity can be understood as a theological reality that finds expression in the social behaviour of the believing community (Lim 2014). In this sense, the in-Christ identity is portrayed as exclusive in that it is not based on anthropological categories but inclusive in that, as a result of the latter, it is indiscriminate. In light of these, the ethnic-reasoning position is thus incompatible with the theological categories in which Paul presents the new identity in Christ, which begs the question if the ethnic-reasoning position is a viable model to interpret identity in the New Testament at all. Although the ethnicreasoning position is not a theological approach as such, as seen from the above discussion, it cannot escape engagement with the theologising of the New Testament authors on identity or engagement with the theology on identity derived from these various authors either.

\section{Acknowledgements Competing interests}

The author has declared that no competing interest exists.

\section{Authors' contributions}

I declare that I am the sole author of this research article.

\section{Ethical consideration}

This article followed all ethical standards for a research without direct contact with human or animal subjects.

\section{Funding information}

This research received no specific grant from any funding agency in the public, commercial or non-profit sectors..

\section{Data availability statement}

Data sharing is not applicable to this article as no new data were created or analysed in this study.

\section{Disclaimer}

The views and opinions expressed in this article are those of the author and do not necessarily reflect the official policy or position of any affiliated agency of the author. 


\section{References}

Balz, H., 1990, 'є் $\theta \varepsilon \lambda 0 \theta \rho \eta \sigma \kappa i ́ \alpha '$, in H.R. Balz \& G. Schneider (eds.), Exegetical Dictionary of the New Testament, vol. 1, p. 381, Eerdmans, Grand Rapids, MI.

Barnett, P., 1997, The Second Epistle to the Corinthians, The New International Commentary on the New Testament, Eerdmans, Grand Rapids, MI.

Barth, F., 1969, 'Introduction', in F. Barth (ed.), Ethnic groups and boundaries: The social organization of culture difference, pp. 9-38, George Allen and Unwin London.

Bauer, W., Danker, F.W., Arndt, W.F. \& Gingrich, F.W. (eds.), 2000, A Greek-English Lexicon of the New Testament and other early Christian Literature, BDAG, University of Chicago Press, Chicago, IL.

Betz, H.D., 1979, Galatians, Hermeneia, Fortress, Philadelphia, PA.

Bowie, F., 2006, 'Anthropology of religion', in R.A. Segal (ed.), The Blackwell companion to the study of religion, pp. 3-24, Blackwell, Malden, MA.

Bruce, F.F., 1982, The Epistle of Paul to the Galatians, The New International Greek Testament Commentary, Paternoster, Exeter.

Bruce, F.F., 1983, The Gospel of John, Eerdmans, Grand Rapids, MI.

Buell, D.K., 2005, Why this new race? Ethnic reasoning in early Christianity, Columbia University Press, New York, NY.

Buell, D.K., 2010, 'God's own people: Specters of race, ethnicity, and gender in early Christian studies', in L. Nasrallah \& E. Schüssler Fiorenza (eds.), Prejudice and Christian beginnings: Investigating race, gender, and ethnicity in early Christianity, pp. 159-190, Fortress, Minneapolis, MN.

Carson, D.A., 1991, The Gospel according to John, Pillar New Testament Commentary, Eerdmans, Grand Rapids, MI.

Ciampa, R.E. \& Rosner, B.S., 2010, The first letter to the Corinthians, Pillar New Testament Commentary, Eerdmans, Grand Rapids, MI.

Concannon, C.W., 2014, 'When you were Gentiles': Specters of Ethnicity in Roman Corinth and Paul's Corinthian Correspondence, Yale University Press, New Haven, CT.

Cranfield, C.E.B., 1975, A critical and exegetical commentary on the Epistle to the Romans, The International Critical Commentary, vol. 1, T\&T Clark, Edinburgh.

Cranfield, C.E.B., 1979, A critical and exegetical commentary on the Epistle to the Romans, The International Critical Commentary, vol. 2, T\&T Clark, Edinburgh.

De Boer, M.C., 2011, Galatians, New Testament Library, Westminster John Knox, Louisville, KY.

Dunn, J.D.G., 1970, Baptism in the Holy Spirit, Fortress, Philadelphia, PA.

Dunn, J.D.G., 1988a, Romans 1-8, Word Biblical Commentary 38a, Word, Dallas, TX. Dunn, J.D.G., 1988b, Romans 9-16, Word Biblical Commentary 38b, Word, Dallas, TX. Dunn, J.D.G., 1993, Galatians, Black's New Testament Commentary, A\&C Black, London.

Dunn, J.D.G., 1996, The Epistles to the Colossians and to Philemon, The New International Greek Testament Commentary, Eerdmans, Grand Rapids, MI.

Elliott, J.H., 2007, 'Jesus the Israelite was neither a "Jew" nor a "Christian": On correcting misleading nomenclature', Journal for the Study of the Historical Jesus 5(2), 119-154. https://doi.org/10.1177/1476869007079741

Fee, G.D., 1994, God's empowering presence: The holy spirit in the letters of Paul, Baker Academic, Grand Rapids, MI.

Fredriksen, P., 2008, Augustine and the Jews: A Christian Defense of Jews and Judaism, Doubleday, New York, NY.

Fredriksen, P., 2010, 'Judaizing the nations: The ritual demands of Paul's Gospel', New Testament Studies 56(2), 232-252. https://doi.org/10.1017/S0028688509990294

Fung, R.Y.K., 1988, The Epistle to the Galatians, The New International Commentary on the New Testament, Eerdmans, Grand Rapids, MI.

Gagnon, R.A.J., 2000, 'Why the "weak" at Rome cannot be non-Christian Jews', Catholic Biblical Quarterly 62(1), 64-82.

Garlington, D.B., 2003, An exposition of Galatians: A new perspective/reformational reading, Wipf \& Stock, Eugene, OR.

George, T., 1994, Galatians, New American Commentary 30, B\&H, Nashville, TN.

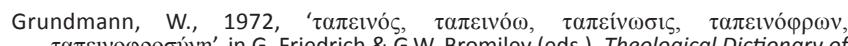
$\tau \alpha \pi \varepsilon 1 v o \varphi \rho о \sigma u v v '$ ', in G. Friedrich \& G.W. Bromiley (eds.), Theological Dictionary of the New Testament, vol. 8, pp. 1-26, Eerdmans, Grand Rapids, MI.

Guthrie, S.E., 2000, 'Projection', in W. Braun \& R.T. McCutcheon (eds.), Guide to the study of religion, pp. 225-238, Continuum, London.

Hansen, G.W., 2009, The Letter to the Philippians, Pillar New Testament Commentary, Eerdmans, Grand Rapids, MI.

Harrill, J.A., 2014, 'Ethnic fluidity in Ephesians', New Testament Studies 60(3), 379402. https://doi.org/10.1017/S0028688514000046

Hays, R.B., 2000, 'The letter to the Galatians', in L.E., Keck (ed.), The New Interpreter's Bible, vol. 11, pp. 181-348, Abingdon, Nashville, TN.

Horrell, D.G., 2016, 'Ethnicisation, marriage and early Christian identity: Critical reflections on 1 Corinthians 7, 1 Peter 3 and Modern New Testament Scholarship', New Testament Studies 62(3), 439-460. https://doi.org/10.1017/ S0028688516000084
Hultgren, A.J., 2011, Paul's Letter to the Romans: A commentary, Eerdmans, Grand Rapids, MI.

Hutchinson, J. \& Smith, A., 1996, 'Introduction', in J. Hutchinson \& A. Smith (eds.), Ethnicity, pp. 3-14, Oxford University Press, Oxford

Jervis, L.A., 1999, Galatians, New International Biblical Commentary on the New Testament, Hendrickson, Peabody, MA.

Jewett, R., 2007, Romans, Hermeneia, Fortress, Minneapolis, MN.

Johnson Hodge, C., 2007, If sons, then heirs: A study of kinship and ethnicity in the Letters of Paul, Oxford University Press, Oxford.

Käsemann, E., 1980, Commentary on Romans, SCM, London.

Kistemaker, S.J., 1993, Exposition of the First Epistle to the Corinthians, Baker Books, Grand Rapids, MI.

Lim, K.Y., 2014, "'If anyone is in Christ, new creation: The old has gone, the new has come" (2 Corinthians 5.17): New creation and temporal comparison in social identity formation in 2 Corinthians', in J.B. Tucker \& C.A. Baker (eds.), T\&T Clark Handbook to Social Identity in the New Testament, pp. 289-310, Bloomsbury, London.

Longenecker, R.N., 1990, Galatians, Word Biblical Commentary 41, Word, Dallas, TX.

Longenecker, R.N., 2016, The Epistle to the Romans, The New International Greek Testament Commentary, Eerdmans, Grand Rapids, MI.

Louw, J.P. \& Nida, E.A. (eds.), 1989, Greek-English Lexicon of the New Testament: Based on Semantic Domains, L\&N, 2nd edn., United Bible Societies, New York, NY.

Martyn, J.L., 1997, Galatians, The Anchor Yale Bible, Yale University Press, New Haven, CT.

Mason, S., 2007, 'Jews, Judaeans, Judaizing, Judaism: Problems of categorization in ancient history', Journal for the Study of Judaism 38(4-5), 457-512. https://doi. org/10.1163/156851507X193108

Mason, S. \& Esler, P.F., 2017, 'Judaean and Christ-follower identities: Grounds for a distinction', New Testament Studies 63(4), 493-515. https://doi.org/10.1017/ S0028688517000145

McCartney, D.G., 2009, James, Baker Exegetical Commentary on the New Testament, Baker Academic, Grand Rapids, MI.

McKnight, S., 2011, The Letter of James, The New International Commentary on the New Testament, Eerdmans, Grand Rapids, MI.

Moo, D.J., 2008, The Letters to the Colossians and to Philemon, Pillar New Testament Commentary, Eerdmans, Grand Rapids, MI.

Moo, D.J., 2013, Galatians, Baker Exegetical Commentary on the New Testament, Baker Academic, Grand Rapids, MI.

Moo, D.J., 2018, The Letter to the Romans, The New International Commentary on the New Testament, 2nd edn., Eerdmans, Grand Rapids, MI.

Munck, J., 1967, Christ \& Israel: An interpretation of Romans 9-11, Fortress, Philadelphia, PA.

Osborne, G.R., 2004, Romans, The IVP New Testament Commentary Series, IVP Academic, Downers Grove, IL.

Pao, D.W., 2012, Colossians \& Philemon, Zondervan Exegetical Commentary on the New Testament, Zondervan, Grand Rapids, MI.

Ridderbos, H.N., 1959, Aan de Romeinen, Commentaar op het Nieuwe Testament, Kok, Kampen.

Ridderbos, H.N., 1966, Ontwerp van Zijn Theologie, Kok, Kampen.

Ridderbos, H.N., 1997, The Gospel according to John: A theological commentary, Eerdmans, Grand Rapids, MI.

Ryken, P.G., 2005, Galatians, Reformed Expository Commentary, P\&R, Phillipsburg, NJ. Schreiner, T.R., 2018, Romans, Baker Exegetical Commentary on the New Testament, 2nd edn., Eerdmans, Grand Rapids, MI.

Sechrest, L.L., 2009, A Former Jew: Paul and the Dialectics of Race, T\&T Clark, London.

Silva, M., 2001, Interpreting Galatians: Explorations in exegetical method, Baker Academic, Grand Rapids, MI.

Thiselton, A.C., 2000, The First Epistle to the Corinthians, The New International Greek Testament Commentary, Eerdmans, Grand Rapids, MI.

Van Kooten, G.H., 2008, Paul's anthropology in context, Mohr Siebeck, Tübingen.

Wallace, D.B., 1996, Greek Grammar beyond the basics: An Exegetical syntax of the New Testament, Zondervan, Grand Rapids, MI.

Wilson, R.McL., 2005, Colossians and Philemon, The International Critical Commentary, Bloomsbury, London.

Witherington, B. III, 1998, Grace in Galatia: A commentary on Paul's Letter to the Galatians, Eerdmans, Grand Rapids, MI

Wright, N.T., 1986, Colossians and Philemon: An introduction and commentary, Tyndale New Testament Commentaries, Inter-Varsity, Nottingham.

Wright, N.T., 2002, 'The letter to the Romans', in L.E. Keck (ed.), The New Interpreter's Bible, vol. 10, pp. 394-770, Abingdon, Nashville, TN.

Zerwick, M. \& Grosvenor, M., 1996, A Grammatical analysis of the New Testament, Editrice Prontificio Istituto Biblico, Rome. 